\title{
Spatial and temporal evaluation of the Water Quality Index and Trophic State Index of the Curuçá River, Maranhão, Brazil
}

\author{
Neemias Muniz de Souza ${ }^{1}$, Wanderson Pedro de Oliveira Carvalho Araújo ${ }^{2}$, \\ Eduardo Henrique Costa Rodrigues ${ }^{3}$ and Maria Raimunda Chagas Silva ${ }^{4}$ \\ ${ }^{1}$ Universidade CEUMA - UniCEUMA, São Luís-Maranhão, Brasil. \\ neemias_munizdesouza@hotmail.com \\ ${ }^{2}$ Universidade CEUMA - UniCEUMA, São Luís-Maranhão, Brasil. \\ pedroeng10@outlook.com \\ ${ }^{3}$ Universidade CEUMA - UniCEUMA, São Luís-Maranhão, Brasil. \\ ehc.1988@hotmail.com \\ ${ }^{4}$ Universidade CEUMA - UniCEUMA, São Luís-Maranhão, Brasil. \\ marirah@gmail.com
}

\begin{abstract}
This work aimed to evaluate the seasonal variations in the Water Quality Index and Trophic State Index in a given period. Physical and chemical analyses were performed according to APHA 2012 methods for water samples collected from the Curuçá River. The physicochemical parameters analyzed were temperature, $p H$, turbidity, total dissolved solids, conductivity, dissolved oxygen, biochemical demand, nitrite, nitrate, and total phosphorus; the results showed that there was significant variation between all the points collected in the dry periods and those established by the CONAMA 357/05. For the WQI, water was in the category of good to optimal, while according to the TSI, the aquatic environment of the Curuçá River was classified as ultraoligotrophic. Non-compliance with environmental norms for nutrients and bacteria was observed. Therefore, the presence of Escherichia coli with a value of $<1000 \mathrm{CFU} / 100 \mathrm{~mL}$ was detected. The data were compared to the CONAMA 357/05, which showed that the data were inadequate for the maintenance of aquatic life. This analysis made it possible to verify the quality of this water, which is of environmental and socioeconomic interest to the population of the region where the springs will have to be preserved to improve the quality of the water.
\end{abstract}

Keywords: Parameters; Quality index; Trophic index 


\section{Introdution}

Knowledge about the water quality of a river basin is of extreme importance because it makes it possible to infer about its condition as a whole. One way to determine water quality is to conduct a temporal and spatial diagnosis, thereby obtaining necessary information for management and intervention actions to recover or preserve the springs and provide better conditions for the sustainability of the ecosystem (VALLE JUNIOR, 2013).

Concern about the degradation of water resources and the prospects for scarcity highlight the need for an effective interpretation of water quality. In the $1990 \mathrm{~s}$, concerned with soil degradation and the sustainability of agricultural ecosystems, the scientific community began to address this theme more intensively and understood soil functions in this context (VEZZANI and MIELNICKZUK, 2009). This fact can be proven by the considerable increase in publications on soil quality in international journals (ARAÚJO et al., 2012). Understanding soil quality can assist in assessing its agricultural suitability and guiding the sustainable use of this resource. Therefore, the monitoring of water quality is one of the main instruments for sustaining a water resources planning and management policy because it acts as a sensor that allows the monitoring of the use of the water courses, thereby presenting its effects on the qualitative characteristics of the waters and aiming at subsidizing environmental control actions (ARAÚJO et al., 2012)

For this purpose, the use of water quality indexes is an alternative for surface water monitoring programs to foresee the possible deterioration of water resources along the river basin or over time (ZANINI, 2010).

According to Souza (2015) and Toledo and Nicolella (2002), the interpretation of surface water quality requires the use of simple methods. For this, the use of water quality indexes is an alternative for surface water monitoring programs to foresee the possible deterioration of water resources along the river basin or over time. Changes in the aquatic system can lead to economic losses for the region ranging from reduced fishing catch to increased water acquisition and treatment costs.

It is essential that water resources have the appropriate physical and chemical conditions for the use of living organisms, contain substances essential to life, and are free from other substances that may have harmful effects on organisms. Therefore, the water quality of a region is determined by natural processes (intensity of precipitation, weathering, and vegetation cover) and anthropic influences (agriculture, urban concentration, industrial activity, and excessive water use) (CRUZ et al., 2007).

Rivers are complex systems characterized as natural drains of the adjacent drainage areas, which in principle form the water basins. The complexity of these lotic systems is due to land use, geology, size, and shape of drainage basins, and local climatic conditions (TOLEDO, 2002). Each lotic system has its own characteristics, which makes it difficult to establish a single variable as a standard indicator for any water system. In this sense, the search for fieldwork is to obtain water quality indexes that briefly and objectively reflect the changes in water quality, with emphasis on human interventions (CRUZ et al., 2007)

Water resources are important for the dynamics of the aquatic ecosystem of Maranhão, where the hydrography of the Island of São Luís, MA comprises a group of small hydrographic basins, such as Anil, Bacanga, Paciência, Tibiri, and Cubs located in São Luís; Antônio Esteves and Santo Antônio in Paço do Lumiar; and Jeniparana in São José de Ribamar (MARANHÃO, 2010). The Santo Antônio River begins in the city district, which is where the highest altitudes of its basin are located, reaching heights of over $60 \mathrm{~m}$. Its total length reaches $25.3 \mathrm{~km}$, and its mouth is located in the Bay of Curupu, which has other denominations, namely Cururuca and São João. Analyzing the course of the Santo Antônio River, Feitosa (1996) found that drainage areas of lower 
population density where anthropic activities are still characterized by rural practices have relatively conservative margins, although the water quality is partially compromised by the high rates of fecal coliform (CF) as well as silting from erosion (BEZERRA, 2001; FERREIRA, 2003).

In the area of the Santo Antônio River Basin, anthropic activities have intensified over the last two decades, thereby causing serious environmental problems due to the construction of engineering works with different levels of interference in the organization of space. The riverbed is suffering from several environmental problems due to the release of domestic effluents, such as silting and water pollution, in order to compromise the domestic use of water. The evaluation of the Water Quality Index (WQI) can support the formulation of management plans for aquatic systems. Thus, the objective of this work was to evaluate the spatiotemporal variation in the WQI and Trophic State Index (TSI) of the Curuçá River, Santo Antônio the River Sub-Basin, using surface water samples.

\section{Materials and méthods}

\subsection{Study Area}

This work was conducted in the lower course of the Curuçá River located in the Santo Antônio River Basin, which is known to residents because it is located in the Santo Antônio neighborhood. It is located in the sub-basin of the Curuçá River in the Municipality of Paço do Lumiar. It is about $21 \mathrm{~km}$ long, and is located between $3^{\circ} 31^{\prime} 59.6^{\prime \prime} \mathrm{S}$ to $43^{\circ} 55^{\prime} 55.7^{\prime \prime} \mathrm{W}$ and $3^{\circ} 31^{\prime} 55.9^{\prime \prime} \mathrm{S}$ to $43^{\circ} 56^{\prime} 03.6^{\prime \prime} \mathrm{W}$, as shown in Figure 1.

Figure 1 - Map of the lower course of the Curuçá River located in the Santo Antônio River Basin in the municipality of Paço do Lumiar, Maranhão

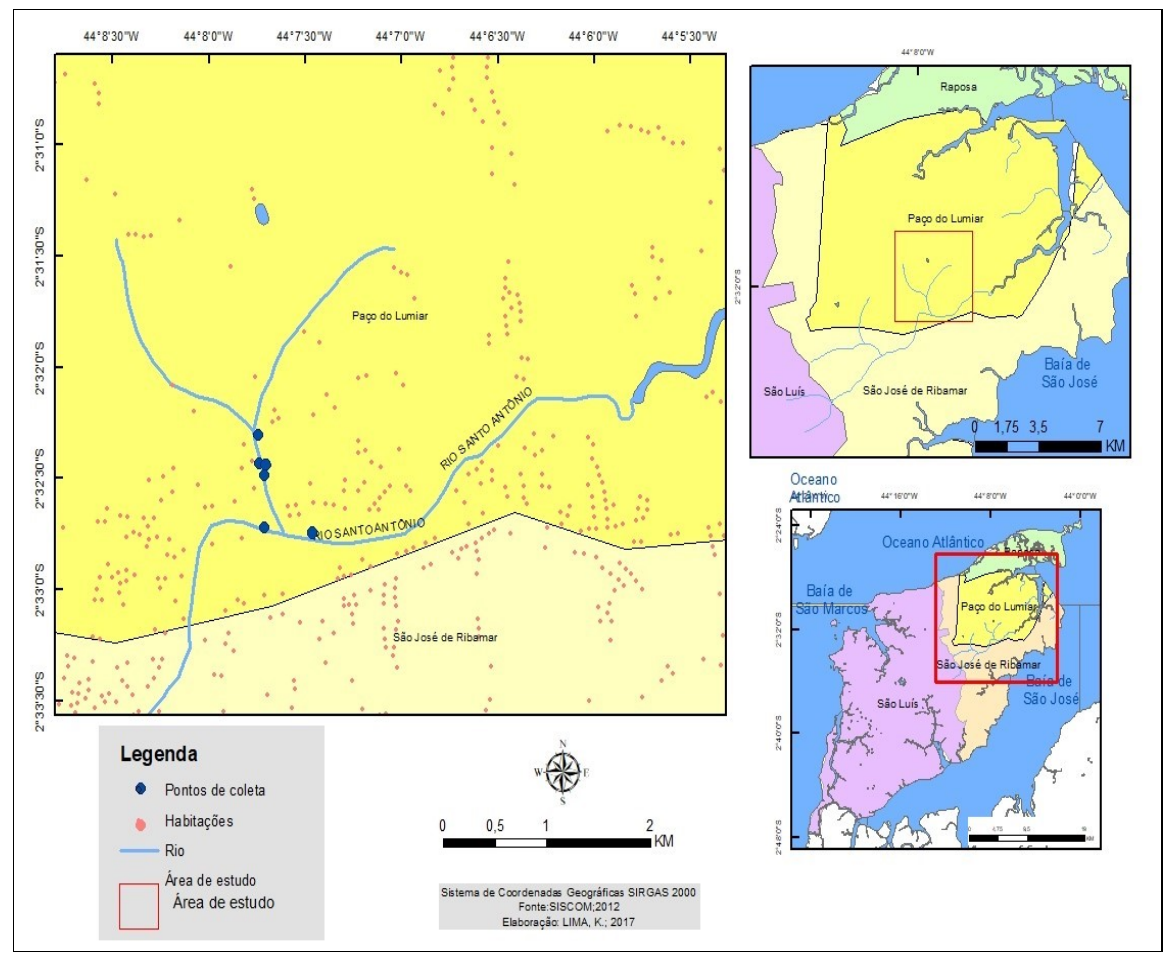




\subsubsection{Data Collection and Analysis}

The monthly precipitation and average temperature data from São Luís Island, MA over 20 years (19812010) were obtained from the National Institute for Space Research and are shown in Figure 2.

Figure 2 - Average precipitation and monthly temperature from 1981-2010 (INPE, 2017)

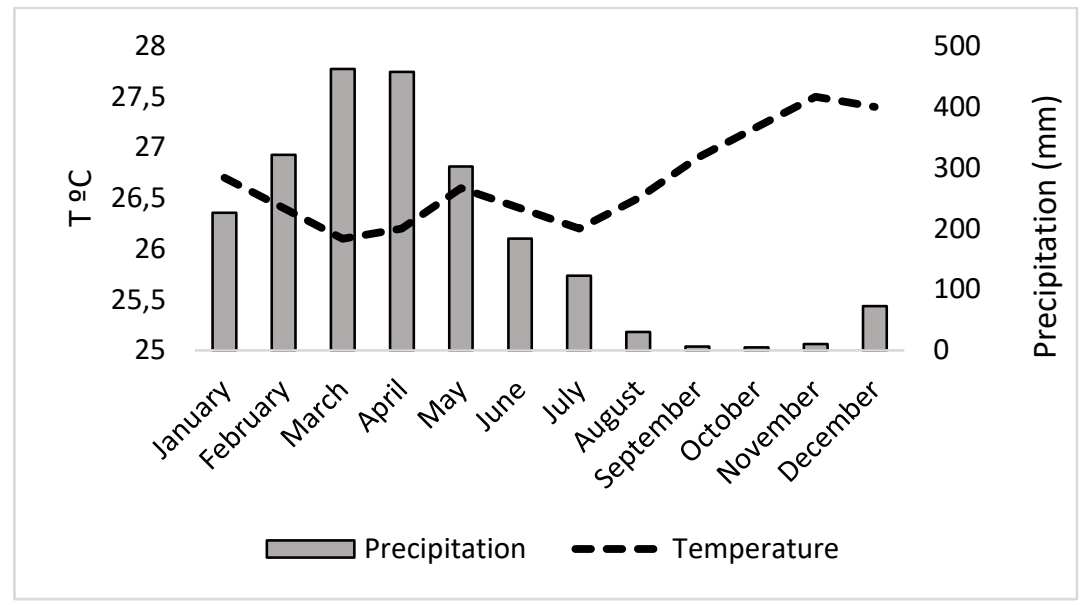

The temporal series of climatic data over 20 years showed that the climate of the region shows a marked difference between the rainy season and dry season. The peaks of precipitation are related to the greater occurrence of rain in the months of March and April. In this way, the data collection conducted in the months of April, May, and June of 2017 was considered the rainy season, while the data collection conducted in the months of August, September, and October characterized the dry period.

Water sampling was conducted in six representative points in the Curuçá River area, namely P1 - bridge entrance, P2 - after bridge, P3 - bridge bar, P4 - river middle, P5 - juçaral, and P6 - river source. All samples were collected in different seasonal periods, namely during the rainy season (April, May, and June) and the dry season (August, September, and October) of 2017. After collection, the bottles were transported to the Laboratory of Environmental Sciences at Ceuma University, and all the measurements were conducted with replicates. The variables were analyzed following the methodology described in APHA (2012).

The physical and chemical parameters were determined using an AK88 portable multiparameter meter. Temperature $\left({ }^{\circ} \mathrm{C}\right)$ (mercury thermometer), $\mathrm{pH}(\mathrm{phg})$, turbidity (NTU) (portable turbidimeter), electrical conductivity (EC), total dissolved solids (TDS), nitrite $\left(\mathrm{NO}_{2}{ }^{-}\right)$, nitrate $\left(\mathrm{NO}_{3}{ }^{-}\right)$, and total phosphorus (PT) were determined using a photometer (Hanna Instruments HI 83200). For the dissolved oxygen concentration (OD) and biochemical oxygen demand (BOD5 days), the method based on the technique described by Winkler and modified according to the procedure quoted in Strickland and Parson (1972) and (SILVA, et al., (2017) was used. The determination of chlorophyll $a(\mathrm{CL})$ was performed using the UV-Vis spectrophotometer method with a Shimadzu UV 1601 spectrophotometer.

For the microbiological analyses, a Colitest kit was used to determine total coliform and CF in the water samples of the river. The indole test was performed to confirm the presence of Escherichia coli using fluorescence as a developer in UV light. The test was considered positive due to the formation of a red ring, and was then seeded on the surface of the agar (Eosin Methylene Blue Agar) medium to obtain and identify E. coli colonies (CETESB, 2010). 
In the incubation, typical colonies of thermotolerant coliform bacteria were read. After obtaining the results, they were compared with the parameters determined by the National Environment Council (CONAMA) Resolution No. 357 of March 17, 2005 (357/05), because the local population uses water from the Curuçá River for consumption (BRASIL, 2005).

The analysis of the limnological variables that make up the WQI and TSI was performed using CETESB annual reports from 2007 to 2010. The WQI is an approximate indication of the state of the water body. For the determination of the WQI, we used Equation 1 (CETESB, 2015):

$$
I Q A=\prod_{i=1}^{n} q i^{w i}
$$

where $Q i$ is the quality value of the $i^{\text {th }}$ parameter, which is a number between 0 and 100 obtained from the respective average curve of quality variation as a function of its concentration or measurement (ANA, 2015); and $w i$ is the weight corresponding to the $i^{\text {th }}$ parameter set as a function of its importance for the overall conformation of the quality, which is a number between 0 and 1 .

For the determination of the TSI, Equations 2, 3, and 4 were used for CL and PT following the method described by Alves et al. (2012) (CETESB, 2015).

$$
\begin{aligned}
& \operatorname{IET}(P T)=10 \cdot\left\{6-\left[\frac{0,42-0,36 \cdot \ln (P T)}{\ln (2)}\right]\right\} \\
& \operatorname{IET}(C L)=10 \cdot\left\{6-\left[\frac{-0,7-0,6 \cdot \ln (C L)}{\ln (2)}\right]\right\} \\
& \operatorname{IET}=\frac{\operatorname{IET}(P T)+\operatorname{IET}(C L)}{2}
\end{aligned}
$$

where TSI (PT) is the TSI determined for phosphorus; TSI (CL) is the determined TSI for CL; PT is the PT concentration measured at the water surface $(\mu \mathrm{g})$; and CL is the measured CL concentration at the surface of the water $(\mu \mathrm{g})$.

The physical and chemical parameters were included in principal component analysis (PCA) in order to verify the association between these variables and the water bodies sampled, as well as the influences of different hydrological periods (JOHNSON and WICHERN, 1998; HONGYU, 2015).

\section{Results and discussion}

The results of the physicochemical and microbiological parameter analyses, WQI, and TSI of the Curuça River Sub-Basin located in the municipality of Paço do Lumiar, MA in the three months of the rainy and dry periods, respectively, in 2017, are presented in Tables 1, 2, and 3 and Figure 3.

\subsection{Physicochemical Variables of Water}

The values of the physicochemical variables analyzed in the months of April, May, and June (rainy season) are presented in Table 1. 
Table 1 - Mean and standard deviation of the values for the physicochemical and microbiological parameters evaluated in samples from the lower course of the Curuçá River.

\begin{tabular}{l|c|c|c}
\hline Parameters & Dry Period & Rainy Period & CONAMA 357/05 \\
\hline Temperature & $26.4 \pm 0.59$ & $28.02 \pm 0.53$ & $30{ }^{\circ} \mathrm{C}$ \\
\hline Electrical conductivity & $182.01 \pm 4.97$ & $152.6 \pm 32.74$ & $100 \mu \mathrm{S} / \mathrm{cm}$ \\
\hline TDS & $92.8 \pm 11.54$ & $141.7 \pm 14.27$ & $500 \mathrm{mg} / \mathrm{L}$ \\
\hline Turbidity & $21.5 \pm 6.07$ & $17.77 \pm 12.09$ & $100 \mathrm{UNT}$ \\
\hline $\mathrm{pH}$ & $7.04 \pm 0.18$ & $7.13 \pm 0.18$ & $6.0 \mathrm{and} 9.5$ \\
\hline OD & $4.73 \pm 0.23$ & $5.41 \pm 0.53$ & $2 \mathrm{mg} / \mathrm{L}$ \\
\hline $\mathrm{BOD}$ days & $5.6 \pm 0.57$ & $9.5 \pm 0.57$ & $1 \mathrm{mg} / \mathrm{L}$ \\
\hline $\mathrm{NO}_{2}{ }^{-}$ & $0.33 \pm 0.05$ & $0.39 \pm 0.16$ & $10 \mathrm{mg} / \mathrm{L}$ \\
\hline $\mathrm{NO}_{3}{ }^{-}$ & $2.0 \pm 0.33$ & $3.1 \pm 0.67$ & $0.03 \mathrm{mg} / \mathrm{L}$ \\
\hline Total phosphorus & $0.11 \pm 0.06$ & $0.34 \pm 0.17$ & $0.01 \mathrm{and} 0.02 \mathrm{mg} / \mathrm{L}$ \\
\hline Chlorophyll $a$ & $0.02 \pm 0.00$ & $0.02 \pm 0.00$ & $>1000 \mathrm{CFU} / 100 \mathrm{mg} / \mathrm{L}$ \\
\hline Thermotolerant coliform bacteria & $1.64 \pm 0.33$ & $2.10 \pm 0.08$ & \\
\hline
\end{tabular}

In the dry period, the temperature varied from 25.3 to $27.8^{\circ} \mathrm{C}(\mathrm{m}=26.4)$. Another parameter evaluated was TDS, which showed values between 58.9 and $134.7 \mathrm{mg} / \mathrm{L}(\mathrm{m}=92.8)$. For EC, values ranged from 132.9 to $333.1 \mu \mathrm{S} / \mathrm{cm}(\mathrm{m}=182.01)$. For turbidity, the values varied from 9.42 to $76 \mathrm{NTU}(\mathrm{m}=21.5)$, whereas for $\mathrm{pH}$, the values were from 6.4 to $7.8(\mathrm{~m}=7.04)$. As for OD, the values were from 3.6 to $5.6 \mathrm{mg} / \mathrm{L}(\mathrm{m}=4.73)$, and those of BOD5 were from 3.2 to $5.9 \mathrm{mg} / \mathrm{L}(\mathrm{m}=5.6)$.

It is understood that the results found in the rainy season for some variables, such as EC, OD, and BOD5 days, were above the limit for natural waters according to the CONAMA Resolution 357/05, whose values are OD of $5 \mathrm{mg} / \mathrm{L}, \mathrm{EC}$ of $100 \mu \mathrm{S} / \mathrm{cm}$, and BOD5 days of 2 and $5 \mathrm{mg} / \mathrm{L}$. This is because EC is inversely proportional to the value of the rainfall index (ESTEVES, 2011). Regarding the analyzed variables, all were within the values allowed by the CONAMA 257/05 legislation for natural waters. Segundo Silva (2017), dados de pH predominantemente ácidos foram obtidos no Rio Pindaré, no município de Tufilândia, e predominante básico no município de Alto Alegre, durante o período seco.

By observing the values found at all points, the $\mathrm{pH}$ of the water was around neutral, and did not show large variation. The $\mathrm{pH}$ value influences the distribution of free and ionized forms of various chemical compounds. The $\mathrm{pH}$ values found could be explained by the influence of litter and deforestation of riparian forests, which causes strong silting that exposes the margin area.

Corroborating this work, Andrade et al. (2016) evaluated the physicochemical characteristics of Macurany Lake in Parintins, AM, and did not observe differences in the characteristics in dry and rainy periods in relation to $\mathrm{pH}$ and temperature. The authors reported that although they did not find differences between these parameters in different periods, there was seasonal variation in the microbial concentration.

The values of the nitrogen $\left(\mathrm{NO}_{2}{ }^{-}\right.$and $\left.\mathrm{NO}_{3}{ }^{-}\right)$variables in the dry period were within the values allowed by

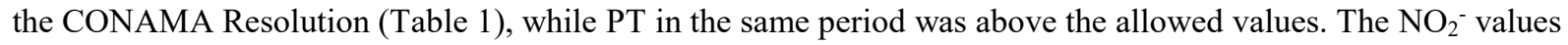


ranged from 0.11 to $0.44 \mathrm{mg} / \mathrm{L}(\mathrm{m}=0.33)$, which presented low variation that did not exceed $0.1 \mathrm{mg} / \mathrm{L}$. This suggested a low incidence of the nitrification process and that the waters of the river were within the established standards for Class 2 water bodies for this parameter. In relation to the observed values of $\mathrm{NO}_{3}{ }^{-}$, there was variation between 1.15 and $4.24 \mathrm{mg} / \mathrm{L}(\mathrm{m}=2.0)$, thereby evidencing the low concentration of $\mathrm{NO}_{3}{ }^{-}$in river waters in the studied period; the concentrations were lower than the limit $(10 \mathrm{mg} / \mathrm{L})$ recommended by the CONAMA Resolution 357/05 (CONAMA, 2005) for Class 2 water bodies.

The values of PT ranged from 0.02 to $0.03 \mathrm{mg} / \mathrm{L}(\mathrm{m}=0.11)$. The high PT content found might have been associated with the discharge of domestic sewage with a high content of phosphate detergents, because it did not exceed what was allowed and was in the rainy season, which is when dilution is higher in the river water. These results were within the limit of $0.030 \mathrm{mg} / \mathrm{L}$ recommended by the CONAMA Resolution 357/05.

Comparing the data from the São Caetano stream located in Balsas, MA from Lima (2017) with the data found in this work, it was observed that there was no similarity between them. In relation to the nitrogen compounds, the concentrations ranged from 0.01 to $0.49 \mathrm{mg} / \mathrm{L}$ for $\mathrm{NO}_{2}{ }^{-}$and from 0.00 to $2.40 \mathrm{mg} / \mathrm{L}$ for $\mathrm{NO}_{3}{ }^{-}$, thereby evidencing the low concentration of $\mathrm{NO}_{3}{ }^{-}$in the waters of the stream in the studied period.

The same parameters were measured for the months of August, September, and October (rainy season), when the temperature data varied from 26.5 to $28.9^{\circ} \mathrm{C}(\mathrm{m}=28.02)$. For TDS, we found variation between 114.9 to $168.1 \mu \mathrm{S} / \mathrm{cm}(\mathrm{m}=141.7)$. For $\mathrm{EC}$, the values were between 115.1 and $165.5 \mu \mathrm{S} / \mathrm{cm}(\mathrm{m}=152.6)$. The variation in turbidity was from 10.44 to $28.12 \mathrm{NTU}(\mathrm{m}=17.77)$. For $\mathrm{pH}$, the values found were from 6.45 to $7.9(\mathrm{~m}=7.13)$. As for OD, the values ranged from 4.8 to $5.87 \mathrm{mg} / \mathrm{L}(\mathrm{m}=5.41)$, and BOD5 varied from 5.8 to $11.42 \mathrm{mg} / \mathrm{L}(\mathrm{m}=$ 9.5).

It is understood that the results found in the dry period for some variables, such as EC, OD, and BOD5 days, were above the limits for natural waters according to the CONAMA Resolution 357/05, whose values are OD of $5 \mathrm{mg} / \mathrm{L}, \mathrm{EC}$ of $100 \mu \mathrm{S} / \mathrm{cm}$, and BOD5 days of $5 \mathrm{mg} / \mathrm{L}$. According to Esteves (2011), this phenomenon occurs due to the fact that EC is inversely proportional to the value of the rainfall index (ESTEVES, 2011). The other variables, namely temperature, TDS, turbidity, and $\mathrm{pH}$, all complied with the limits recommended by the CONAMA Resolution 357/05 for natural waters.

As for the chemical parameters, $\mathrm{NO}_{2}{ }^{-}$concentrations ranged from 0.32 to $0.56 \mathrm{mg} / \mathrm{L}(\mathrm{m}=3.1)$. Despite the variations, the values obtained from the points were within the limit established by the CONAMA Resolution $357 / 05$, which is $1 \mathrm{mg} / \mathrm{L}$. This suggested the low incidence of nitrification. When considering $\mathrm{NO}_{2}^{-}$, it could be stated that the river waters were within the established standards for Class 2 water bodies.

$\mathrm{NO}_{3}{ }^{-}$presented concentrations ranging from 2.20 to $3.68 \mathrm{mg} / \mathrm{L}(\mathrm{m}=0.39)$, thereby evidencing a low concentration of $\mathrm{NO}_{3}{ }^{-}$in the waters of the river in the studied period that was lower than the limit recommended by the CONAMA Resolution 357/05 for Class 2 water bodies, which is $10 \mathrm{mg} / \mathrm{L}$.

For the PT concentration, the values varied from 0.22 to $0.48 \mathrm{mg} / \mathrm{L}(\mathrm{m}=0.34)$. The high phosphorus content found may have been associated with the discharge of domestic sewage with high contents of phosphate detergents. These results were above the $0.030 \mathrm{mg} / \mathrm{L}$ limit of the CONAMA Resolution 357/05.

Phosphorus is the main limiting factor of productivity in water bodies and has been identified as the main responsible for the artificial eutrophication of these ecosystems, i.e., a greater amount of organic matter is produced than is consumed and decomposed. Phosphorus can originate from natural sources (present in the composition of rocks, carried by surface runoff from rainwater, particulate matter present in the atmosphere, and from the 
decomposition of organisms of allochthonous origin) and artificial sources, such as domestic and industrial sewage, agricultural fertilizers, and particulate matter of industrial origin contained in the atmosphere (WETZEL, 2000; ESTEVES, 2011; BUZELLI et al., 2013).

According to Tundisi (2008), the concentration of these compounds depends on geochemical processes. The values found in this study were higher than those found by Guimarães (2011) in the Gurguéia River Basin in the state of Piauí.

The results of the observed seasonal variations in bacteria of the group of thermotolerant coliforms were $1.43 \times 10^{2} \mathrm{CFU} / 100 \mathrm{~mL}$ to $1.68 \times 10^{2} \mathrm{CFU} / 100 \mathrm{~mL}(\mathrm{~m}=1.64)$ in the rainy season (April, May, and June) and 2.10 $\mathrm{x} 10^{2} \mathrm{CFU} / 100 \mathrm{~mL}$ to $3.53 \times 10^{2} \mathrm{CFU} / 100 \mathrm{~mL}(\mathrm{~m}=2.10)$ in the dry season (August, September, and October), which were considered to be very significant among the sampling points for pathogenic bacteria. The quantified values did not exceed the limit of $>1000 \mathrm{CFU} / 100 \mathrm{~mL}$ established by the CONAMA Resolution 357/05; therefore, they were considered unfit for recreational water. The main source of CF for the waters of the river was the discharge of sewage (mainly domestic sewage) without previous treatment.

Microbiological analyses indicated that although bacteria and E. coli (thermotolerant) were found, which was indicative of fecal contamination, the values did not exceed the limit determined in the literature. Corroborating this work, Fernandes et al. (2017) indicated that the water in the Moisinho Dam, although contaminated by domestic sewage sludge and garbage, among others, had values of bacteria during the dry and rainy periods that did not exceed the values determined by the CONAMA Resolution 357/05, as they were less than $1000 \mathrm{CFU} / 100 \mathrm{~mL}$.

\subsection{Statistical Analysis}

Limnological variables (OD, $\mathrm{pH}$, temperature, $\mathrm{EC}$, turbidity, TDS, $\mathrm{BOD}, \mathrm{NO}_{2}^{-}, \mathrm{NO}_{3}{ }^{-}$, and PT) were included in the PCA to verify the association between these variables with the water bodies sampled, as well as the influences of the different hydrological periods, as shown in Figure 3.

Figure 3 - Graph of principal component analysis of water samples collected from the Curuçá River Sub-Basin at specified points, namely P1 - bridge entrance, P2 - after bridge, P3 - bar, P4 - river middle, P5 - juçaral, P6 spring, in dry ( S) and rainy seasons (c) of 2017

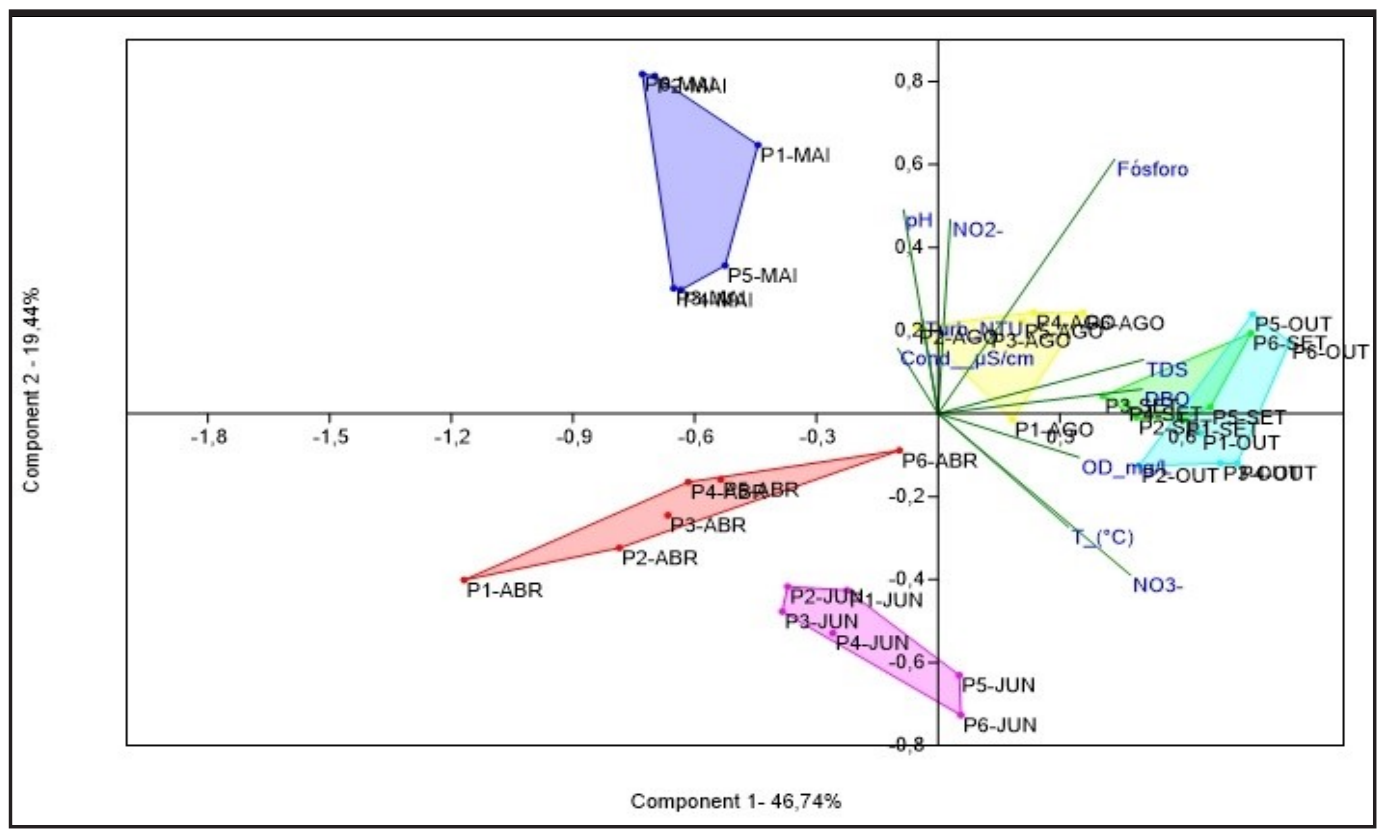


It was possible to determine the spatial and temporal heterogeneity using PCA, which clearly separated the data from dry and rainy periods and gathered them in six sampling seasons. Still, according to the PCA, there was no differentiation between the data in the months of October and September, as they were considered similar, which could be explained by the proximity of the sampling time. Axis 1 explains $46.74 \%$ of the variations, while axis 2 explains $19.44 \%$ of the variations.

In order to evaluate the influence of the conditioning variables, namely $\mathrm{EC}$, suspended solids, $\mathrm{pH}$, turbidity, and OD, through the PCA, Silva et al. (2017) observed that the characteristics of three stretches of the Pindaré River Basin (Pindaré-Mirim, Tufilândia, and Alto Alegre) in the dry and rainy seasons (c) of 2010 and 2011 were very similar to those in the dry and rainy seasons in the Curuçá River.

\subsection{Determination of the Water Quality Index and Trophic State Index Values of the Curuçá River Water}

From the results obtained in the samples, calculations of the seven parameters of the physicochemical variables of the adjusted WQI were conducted, since the sum of the correction factor has to be 1 . Since we did not use two parameters (nitrogen and solid residues), the respective weights were transferred to the other parameters (turbidity, OD, and BOD5), from the adaptation of their Qi, of correction, so that the values were elaborated and obtained with exactitude, in relation to the category according to the classification of the quality of the water, in a scale of 0 to 100 . The water quality was a function of the value of the WQI varying on a scale from 0 to 100 . The quality of the water will depend on the value of the WQI obtained in Table 1. The categories and weighting of the WQI were very bad (WQI $\leq 25)$, bad $(26 \leq \mathrm{WQI} \leq 50)$, regular $(51 \leq \mathrm{WQI} \leq 70)$, good $(71 \leq \mathrm{WQI} \leq 90)$, or excellent $(91 \leq \mathrm{WQI} \leq 100)$ (ANA, 2015; CETESB, 2010). Table 2 shows the results of the WQI of the surface water of the sub-basin of the Curuçá River in Paço do Lumiar, MA.

Table 2 - Results and classification of the Water Quality

\begin{tabular}{|c|c|c|c|c|c|c|}
\hline Month & & & Collec & ints & & \\
\hline \multirow{2}{*}{ April } & $\mathrm{P} 1$ & P2 & P3 & $\mathrm{P} 4$ & P5 & P6 \\
\hline & 66.82 & 68.70 & 70.86 & 71.17 & 74.77 & 75.44 \\
\hline \multirow{3}{*}{ May } & $\mathrm{P} 1$ & $\mathrm{P} 2$ & P3 & $\mathrm{P} 4$ & P5 & P6 \\
\hline & 81.05 & 78.15 & 77.55 & 88.18 & 99.21 & 94.70 \\
\hline & 79.83 & 80.29 & 77.65 & 90.00 & 87.28 & 70.59 \\
\hline \multirow{2}{*}{ August } & $\mathrm{P} 1$ & $\mathrm{P} 2$ & P3 & $\mathrm{P} 4$ & P5 & P6 \\
\hline & 91.30 & 84.62 & 86.08 & 85.31 & 76.26 & 95.44 \\
\hline \multirow{2}{*}{ September } & P1 & $\mathrm{P} 2$ & P3 & P4 & P5 & P6 \\
\hline & 95.73 & 78.24 & 77.95 & 79.78 & 83.65 & 97.53 \\
\hline \multirow{2}{*}{ October } & $\mathrm{P} 1$ & $\mathrm{P} 2$ & P3 & $\mathrm{P} 4$ & P5 & P6 \\
\hline & 99.63 & 80.58 & 81.88 & 82.44 & 84.84 & 99.01 \\
\hline
\end{tabular}


Table 3 - Categories and weighting of the Water Quality Index used to verify the water quality category of the results.

\begin{tabular}{|c|c|c|c|c|c|}
\hline Category & GREAT & GOOD & REGULAR & BAD & VERY BAD \\
\hline Weighting & $79 \leq \mathrm{WQI} \leq 100$ & $51 \leq \mathrm{WQI} \leq 79$ & $36 \leq \mathrm{WQI} \leq 51$ & $19 \leq \mathrm{WQI} \leq 36$ & $\mathrm{WQI} \leq 19$ \\
\hline
\end{tabular}

*Category weighting (ANA, 2015; CETESB, 2010)

Table 4 - Classification of the Trophic State Index (TSI) for the seasonal period of the months of June and September of 2017

\begin{tabular}{|c|c|c|c|c|c|}
\hline Points & $\begin{array}{l}\text { Seasonal } \\
\text { period }\end{array}$ & $\begin{array}{l}P \text {-Total } \\
(\mathrm{mg} / \mathrm{L})\end{array}$ & $\begin{array}{l}\text { Chlorophyll } \\
(\mathrm{mg} / \mathrm{L})\end{array}$ & TSI total & Status \\
\hline \multirow[b]{2}{*}{ P1 } & $\mathbf{R}$ & 28.2 & 13.2 & 20.7 & Ultraoligotrophic \\
\hline & D & 28.1 & 14.5 & 21.3 & \\
\hline \multirow{2}{*}{$\mathbf{P 2}$} & $\mathbf{R}$ & 15.8 & 13.2 & 14.5 & Ultraoligotrophic \\
\hline & D & 27.7 & 14.6 & 21.4 & \\
\hline \multirow{2}{*}{$\mathbf{P 3}$} & $\mathbf{R}$ & 15.8 & 14.4 & 14.5 & Ultraoligotrophic \\
\hline & D & 28.2 & 14.6 & 21.3 & \\
\hline \multirow{2}{*}{$\mathbf{P 4}$} & $\mathbf{R}$ & 15.8 & 14.4 & 14.5 & Ultraoligotrophic \\
\hline & D & 28.4 & 14.7 & 21.4 & \\
\hline \multirow{2}{*}{ P5 } & $\mathbf{R}$ & 16.6 & 14.4 & 15.5 & Ultraoligotrophic \\
\hline & D & 28.5 & 14.6 & 25.7 & \\
\hline \multirow{2}{*}{ P6 } & $\mathbf{R}$ & 17.6 & 14.8 & 25.7 & Ultraoligotrophic \\
\hline & D & 30.5 & 17.1 & 23.6 & \\
\hline \multirow{2}{*}{$*$ Mean \pm SD } & $\mathbf{R}$ & $18.3 \pm 4.48$ & $14.06 \pm 0.63$ & $17.56 \pm 4.25$ & \\
\hline & D & $28.57 \pm 0.90$ & $14.68 \pm 0.78$ & $22.45 \pm 1.67$ & \\
\hline
\end{tabular}

The classification of the aquatic environment according to the TSI for the Curuçá River was ultraoligotrophic, as PT varied between 15.8 and $28.5 \mathrm{mg} / \mathrm{L}$ and CL varied between 13.3 and $14.8 \mathrm{mg} / \mathrm{L}$ in the dry season. For the rainy season, the variation in PT was from 17.6 to $28.5 \mathrm{mg} / \mathrm{L}$, and that of CL was from 21.3 to 23.6 $\mathrm{mg} / \mathrm{L}$; this was considered very significant and totaled less than 14.5 to $20.7 \mathrm{mg} / \mathrm{L}$ for the two stations, which corresponded to a $\mathrm{TSI} \leq 47$ according to ANA (2015).

For both periods, the concentration of this variable was within the limits established by the legislation, because according to the CONAMA Resolution 357/05, for a water body to be classified in Classes 1 , 2, and 3, the maximum values allowed for this parameter are $10 \mu \mathrm{g} / \mathrm{L}, 30 \mu \mathrm{g} / \mathrm{L}$, and $60 \mu \mathrm{g} / \mathrm{L}$, respectively thus, the Curuçá River was classified as Class 1. 
The classification of the TSI of the aquatic environment is given in six trophic degrees. For rivers, the TSI categories are ultraoligotrophic (TSI $\leq 47)$, oligotrophic $(47<\mathrm{TSI} \leq 52)$, mesotrophic $(52<\mathrm{TSI} \leq 59)$, eutrophic $(59<\mathrm{TSI} \leq 63)$, supereutrophic $(63<\mathrm{TSI} \leq 67)$, and hypereutrophic (TSI $>67)$ (ANA, 2015).

$\mathrm{CL}$ is an important variable in aquatic ecosystems as it is the main pigment responsible for photosynthesis. It can be considered an indicator of the trophic state of aquatic environments, as it indicates the algal biomass present in the water body (ESTEVES, 2011).

The TSI was calculated with the purpose of classifying the Curuçá River in trophic degrees, that is, to evaluate the quality of the water by nutrient enrichment and its effect on the excessive growth of algae or the increase in infestation of aquatic macrophytes (LAMPARELLI, 2004).

To determine the degree of eutrophication of an aquatic ecosystem, Carlson (1977) proposed the TSI for temperate environments. In Brazil, this index was modified and adapted to tropical and subtropical environments by Toledo Jr. et al. (1983), Salas and Martino (1991), and, more recently, Lamparelli (2004). A TSI update was proposed by Cunha et al. (2013b) for reservoirs in tropical and subtropical environments. These indexes classify aquatic ecosystems in different trophic degrees, from ultraoligotrophic, which has smaller concentrations of nutrients, to hypereutrophic (FRASCARELI et al., 2015). The Curuçá River is under the same conditions as those of ultraoligotrophic subtropical environments, such as in the state of Maranhão.

\section{Conclusions}

The physicochemical parameters showed significant variations in the river waters located in the areas of Paço do Lumiar, MA, thereby indicating strong anthropic impacts due to the discharge of domestic effluents in the surroundings of the rivers.

Non-compliance with environmental norms for nutrients and bacteria was observed because the concentrations of $E$. coli or thermotolerants in all samples had values of $<1000 \mathrm{CFU} / 100 \mathrm{~mL}$, which is the limit established by the CONAMA Resolution 357/05. Thus, the analyses showed that bacteria were present in the samples, but the levels were inadequate for the maintenance of aquatic life.

The results showed that the studied region presents some adversities in relation to the maximum values established by official bodies, such as CONAMA (BRASIL, 2005), ANA (2015), and CETESB (2015), which are responsible for these types of environments, and indicated that indexes that allow the classification of aquatic ecosystems according to different trophic degrees classified the water as ultraoligotrophic, as it had lower concentrations of nutrients.

This analysis made it possible to verify the quality of this water, which is of environmental and socioeconomic interest to the population of the region. In turn, protection of springs, including land management at the river basin level, is the most efficient way to use the resources of the region because it aims at preserving and improving the quantity and quality of water.

\section{Acknowledgments}

The authors would like to thank Ceuma University. 


\section{References}

AGÊNCIA NACIONAL DE ÁGUAS - ANA. Portal da qualidade das águas. Indicadores de qualidade. Índice de qualidade das águas (IQA). 2015. Disponível em: http://portalpnqa.ana.gov.br/indicadores-indice-aguas. aspx. Acesso em: 15 abr. 2018.

ALVES, Igor Charles Castor; El-ROBRINI, Maâmar; SANTOS, Maria de Lourdes Souza; MONTEIRO, Sury de Moura; BARBOSA, Leandro Patrick Ferreira; GUIMARÃES, José Tasso Felix. Qualidade das águas superficiais e avaliação do estado trófico do Rio Arari (Ilha de Marajó, norte do Brasil,2012.

AMERICAN PUBLIC HEALTH ASSOCIATION - APHA. Standard methods for examination of water and wastewater. 22th ed. Baltimore: United Book Press; 2012.

ANDRIETTI, GRASIANE; FREIRE, ROSANE; AMARAL, ADRIANA GARCIA DO; ALMEIDA, FREDERICO TERRA DE; BONGIOVANI, MILENE CARVALHO; SCHNEIDER, ROSELENE MARIA. Índices de qualidade da água e de estado trófico do rio Caiabi, MT doi:10.4136/ambi-água.1769. Received: 02 Oct. 2015; Accepted: 30 May. 2018

ARAÚJO, R. GOEDERT W.J., LACERDA M.P.C. (2007). Qualidade de um solo sob diferentes usos e sob cerrado nativo. Revista Brasileira de Ciência do Solo, Viçosa, v.31, p.1099-1108.

BEZERRA, J. F. R. MACHADO, J. V. e FEITOSA, A. C. Estudos dos Parâmetros Morfométricos da Bacia do Rio Santo Antônio, município de Paço do Lumiar - MA.In: Anais do IX Simpósio Brasileiro de Geografia Aplicada. Recife, 2001.

BUZELLI, G. M.; CUNHA-SANTINO, M. B. Análise e diagnóstico da qualidade da água e estado trófico do reservatório de Barra Bonita (SP). Ambi-Água, Taubaté, v. 8, n. 1, p. 186-205, 2013. (http://dx.doi.org/10.4136/ ambi-agua.930)

CARLSON, R. E. A trophic state index for lakes. Limnology and Oceanography, v. 2, n. 2, p. 361-369, 1977.

COMPANHIA ESTADUAL DE TECNOLOGIA DE SANEAMENTO BASICO E DE DEFESA DO MEIO AMBIENTE CETESB (2007). Relatório de Qualidade das Águas Interiores no Estado de São Paulo: 2006. São Paulo: CETESB, 2007. (Série Relatórios).

COMPANHIA AMBIENTAL DO ESTADO DE SÃO PAULO - CETESB. Índices de qualidade das águas. 2008. Disponível em:http://www.cetesb.sp.gov.br/userfiles/file/agua/aguas-superficiais/aguas-interiores/ documentos/indices/01.pdf. Acesso em: 17 ago. 2015.

COMPANHIA AMBIENTAL DO ESTADO DE SÃO PAULO - CETESB.. Relatório de qualidade das águas interiores do Estado de São Paulo. São Paulo: CETESB, 2003. p. 264.

BRASIL. CONSELHO NACIONAL DO MEIO AMBIENTE - CONAMA. Resolução Conama n 357, 17 de março de 2005.

CRUZ, PATRÍCIA; REIS, LAYARA; BARROS, ARYANNE; NEVES, JOSYANNE; CÂMARA, FLOR. Comparativo da qualidade físico-química da água no período chuvoso e seco na confluência dos Rios Poti e Parnaíba em Teresina/PI. 2007.

EMPRESA BAIANA DE ÁGUAS E SANEAMENTO S.A. (EMBASA). Rua São Mamede 96, Village Ouro Preto, casa 4, Santa Mônica, 44050-400, Feira de Santana BA. bioritassis@superig.com.br Universidade Estadual de Feira de Santana (UEFS).

ESTEVES, F. A. Fundamentos de limnologia, 3.ํed. Rio de Janeiro. Interciência. 826p, 2011.

FEITOSA, A. C., 1996. Parâmetros analíticos dos sedimentos da praia do Canto, Paço do Lumiar - Ma. In: 3a Reunião Especial da SBPC, 1996, Florianópolis. Ecossistemas costeiros: do conhecimento à gestão. Florianópolis: UFSC, v. 1: 408-409. 
FERNANDES, et al. ESTUDOS MULTIDISCIPLINARES NA ARÉA DA SAÚDE. Analise físico-química e microbiológica da água de um açude do município de vargem grande, Maranhão1 ed.CRV. Curitiba, 2017.168 p.

FERREIRA KÁSSIA CRISLAYNE DUARTE; LOPES, FERNANDO BEZERRA; ANDRADE, EUNICE MAIA DE; MEIRELES, ANA CÉLIA MAIA; SILVA, GERLANGE SOARES DA. Adaptação do índice de qualidade de água da National Sanitation Foundation ao semiárido brasileiro. Adapting the National Sanitation Foundation water quality index to the Brazilian semiarid

FRASCARELI, DANIELE; BEGHELLI, FREDERICO GUILHERME DE SOUZA, SILVA, SHEILA CARDOSO DA, ET AL. Ambient. Água vol. 10 n. 4 Taubaté - Oct. / Dec. 2015.

GUIMARÃES, G. S. C. Estimativas de cargas de fósforo total e de material particulado em suspensão (MPS) da bacia superior do rio Gurguéia. Monografia, Universidade Federal do Piauí-UFPI, 2011.

HONGYU, K. Comparação do GGE biplot ponderado e AMMI-ponderado com outros modelos de interação genótipo × ambiente. Tese (Doutorado em Estatística e Experimentação Agronômica) - Escola Superior de Agricultura "Luiz de Queiroz", Universidade de São Paulo, Piracicaba, 2015. 155p.

LAMPARELLI, M. C. Grau de trofia em corpos d'água do estado de São Paulo: avaliação dos métodos de monitoramento. São Paulo: USP/ Departamento de Ecologia. 2004. 235 f. Tese de doutorado, Universidade de São Paulo, 2004.

MARANHÃO, SECRETARIA DE ESTADO DO MEIO AMBIENTE E RECURSOS HÍDRICOS. Diagnóstico dos Principais Problemas Ambientais do Estado do Maranhão. São Luís, 2010.

SALAS, H. J.; MARTINO, P. A simplified phosphorus trophic state model for warm-water tropical lakes. Walter Research, v. 25, n. 3, p. 341-350, 1991. http://dx.doi.org/10.1016/0043-1354(91)90015-I

SILVA, et al. Qualidade da Água da Bacia do Rio Pindaré, nos trechos correspondentes aos Municípios de Pindaré- Mirim, Tufilândia e Alto Alegre no Estado do Maranhão. Águas Subterrâneas. V. 31 nº 4, p.347-354, 2017.

SILVA, M. R.; SILVA, L. V.; BARRETO, L. N.; C.; RODRIGUES, E. H. C.; MIRANDA, R. C. M.; BEZERRA, D. S. PEREIRA, D. C. A. Águas Subterrâneas, v. 31, n. 4, p. 347-354, 2017. Qualidade da Água da Bacia do Rio Pindaré, nos trechos correspondentes aos Municípios de Pindaré- Mirim, Tufilândia e Alto Alegre no Estado do Maranhão.http://www.inpe.br/institucional/sobre_inpe/cooperacao nacional.php/UEMA.2017.

SOUZA, A.; BERTOSSI, A. P. A; LASTORIA, G. Diagnóstico temporal e espacial da qualidade das águas superficiais do Córrego Bandeira, Campo Grande, MS. Revista Agro@mbiente online, v. 9, n. 3, p. 227-234, 2015.

TOLEDO, L.G. de; NICOLELLA, G. Índice de qualidade de água em microbacia sob uso agrícola e urbano. Scientia Agricola, Piracicaba, v.59, n.1, p.181-186, 2002.

TUNDISI, J. G. Recursos hídricos no futuro: problemas e soluções. Estudos Avançados, v.22, n. 63, p. 7-16, 2008. http://dx.doi.org/10.1590/S0103-40142008000200002

VALLE JÚNIOR, R. F. do; ABDALA, V. L.; GUIDOLINI, J. F.; SIQUEIRA, H. E.; CANDIDO, H. G. Diagnostico temporal e espacial da qualidade das águas superficiais do Rio Uberaba - MG. Caminhos de Geografia, v.14, n.45, p.01-11, 2013.

VEZZANI, F. M.; MIELNICZUC, J. (2009). Uma visão sobre qualidade do solo. Revista Brasileira de Ciência do Solo, v.33, p.743-755.

WETZEL, R. G. Limnology. San Diego: Academic Press, 2001. 1006 p.

ZANINI, HELEN L. H. T; AMARAL, LUIZ A. DO; ZANIN, JOSÉ R; TAVARES, LUCIA H. S. Caracterização da água da microbacia do córrego rico avaliada pelo índice de qualidade de água e de estado trófico. Eng. Agríc., Jaboticabal, v.30, n.4, p.732-741, jul./ago. 2010. 